\title{
Investigating the Management of Geological Hazards and Risks in the Mt Cameroon Area Using Focus Group Discussions
}

\author{
Mary-Ann del Marmol $\odot$, Karen Fontijn, Mary Atanga, \\ Steve Njome, George Mafany, Aaron Tening, \\ Mabel Nechia Wantim, Beatrice Fonge, Vivian Bih Che, \\ Aka Festus, Gerald G. J. Ernst, Emmanuel Suh, \\ Patric Jacobs and Matthieu Kervyn
}

\begin{abstract}
The scientific evaluation of hazards and risks remains a primary concern in poorly known volcanic regions. The use of such information to develop an effective risk management structure and risk reduction actions however also poses important challenges. We here present the results of a series of focus group discussions (FGDs) organised with city councillors from three municipalities around Mt Cameroon volcano, Cameroon. The Mt Cameroon area is a volcanically and tectonically active region regularly affected in the historical past by lava flows, landslides and earthquake swarms, and has a potential for crater lake outgassing. The lower flanks of the volcano are densely populated and the site of intense economic development. The FGDs were aimed at the elicitation of (1) the knowledge and perception of geological hazards, (2) the state of preparedness and the implementation of mitigation and prevention actions by the municipalities, (3) the evaluation of the effectiveness of the structure of communication channels established to respond to emergency situations, and (4) the recovery from an emergency. In all three municipalities stakeholders had good knowledge of the risks, except for
\end{abstract}

M.-A. del Marmol $(\bowtie) \cdot$ K. Fontijn · G. G. J. Ernst . P. Jacobs

Department of Geology, Ghent University,

Krijgslaan 281/S8, 9000 Ghent, Belgium

e-mail: jp.m.malingreau@gmail.com

\section{K. Fontijn}

Department of Earth Sciences, University of Oxford, South Parks Road, Oxford OX1 3AN, UK

S. Njome - G. Mafany - A. Tening - M. N. Wantim •

B. Fonge - V. B. Che - A. Festus - E. Suh

Department of Geology and Environmental Science, University of Buea, P.O. Box 63, Buea, Cameroon

Advs in Volcanology (2018) 373-394

https://doi.org/10.1007/11157_2017_3

(C) The Author(s) 2017

Published Online: 12 April 2017
M. Atanga

Department of Nursing, University of Bamenda, P.O. Box 39, Bambili, NW Region, Bamenda, Cameroon

G. Mafany · A. Festus

Ministry of Scientific Research and Innovation, Institut de Recherches Géologiques et Minières, BP 4110 Yaounde, Cameroon

M. Kervyn

Department of Geography, Vrije Universiteit Brussel, 1050 Brussels, Belgium 
processes never experienced in the region. They generally grasped the causes of landslides or floods but were less familiar with volcano-tectonic processes. Stakeholders identified the lack of strategic planning to monitor hazards and mitigate their impacts as a major weakness, requesting additional education and scientific support. Response to natural hazards is mostly based on informal communication channels and is supported by a high level of trust between local scientists, decision makers and the population. Actions are taken to raise awareness and implement basic mitigation and prevention actions, based on the willingness of local political leaders. The strong centralisation of the risk management process at the national level and the lack of political and financial means at the local level are major limitations in the implementation of an effective risk management strategy adapted to local risk conditions. Our case study highlights the need for earth and social scientists to actively work together with national and local authorities to translate the findings of scientific hazard and risk assessment into improved risk management practices.

\section{Keywords}

Mount Cameroon - Focus group discussion - Natural hazard - Risk management $\cdot$ Landslide $\cdot$ Volcanic activity

\section{Introduction}

\subsection{Mount Cameroon: General Setting and Types of Natural Hazards}

Mount Cameroon in SW Cameroon is one of the largest (4095 m high) flow-dominated volcanoes on Earth, and one of the most frequently active volcanoes in Africa (Siebert et al. 2010). It has a NW-SE elongated shape of about 50 by $35 \mathrm{~km}$ and is part of the Cameroon Volcanic Line, a chain of Cenozoic volcanic structures extending about $2000 \mathrm{~km}$ from the Gulf of Guinea to the Adamawa Plateau in Tchad (e.g. Déruelle et al. 2007; Njome and de Wit 2014). Mount Cameroon erupted seven times in the 20th century, the last two confirmed eruptions taking place in 1999 and 2000 (Suh et al. 2003, 2008). The eruptive style generally comprises effusive and Strombolian-style activity, the latter mostly confined to the broad summit region. Basaltic lava flows occur predominantly along the NE and SW flanks of the volcano. These lava flows are relatively mobile, reaching lengths of up to $9 \mathrm{~km}$ (Bonne et al. 2008; Favalli et al. 2011; Njome et al. 2008; Wantim et al. 2013a, b ), and thus pose a potential threat to communities at the base of the volcano. Favalli et al. (2011) and Wantim et al. (2013b) developed idealised lava flow models to be used as a base to alert and potentially evacuate communities at risk of advancing lava flows. Historical eruptions of Mount Cameroon were associated with destruction of plantations and farmland, critical infrastructure such as roads and bridges, as well as houses (e.g. in 1922 and 1999: Déruelle et al. 1987; Suh et al. 2003, 2011). Eruptions were typically also associated with health risks like respiratory problems and contaminated water supplies (e.g. in 1999: Atanga et al. 2009).

Other natural hazards occurring in the Mount Cameroon area include landslides (Che et al. 2011, 2012a, b), especially on the SE flank which records at least one landslide every year. These landslides occur on old hilly volcanic terrain with deeply weathered soils which are cultivated by a growing population (Che et al. 2012a, b). 
However, because most of these landslides have not caused fatalities in the past, they are not always recorded or reported (Ayonghe et al. 2004; Diko 2012). Floods (Ndille and Belle 2014), crater lake outgassing and different types of earthquakes are other natural hazards that characterise the Cameroon Volcanic Line. Disastrous crater lake outgassing has occurred twice in the early 1980s at Lakes Monoun and Nyos (Freeth and Kay 1987; Issa et al. 2014). The local population strongly fears earthquakes because they have led to the destruction of houses and other infrastructure on numerous occasions in the past. Ateba et al. (2009) describe the seismic activity as "co-eruptive", noting that the 2000 eruption was characterised by sequences of earthquake swarms and volcanic tremor. The Global Network for Disaster Reduction reports in 2011 that about $25 \%$ of the natural hazards in Cameroon occur along the Cameroon Volcanic Line (GEADIRR 2011).

\subsection{Project Motivation}

The Mount Cameroon area is exposed to a variety of natural hazards and associated risks (Fig. 1). Donovan et al. (2014) suggest that Mount Cameroon is considered as a low risk potential, due to the predominantly effusive nature of its eruptions, but with an extremely high likelihood of an eruption in the next 30 years. A number of volcanic hazard and risk assessments have been performed (Bonne et al. 2008; Thierry et al. 2008; Favalli et al. 2011; Gehl et al. 2013) but these have largely been limited to scientific publications. Translation of relevant scientific information into understandable language for the local population is yet to be fully implemented in the area, and will facilitate the delivery of more efficient assistance in preparedness and response to natural hazards (e.g. Barclay et al. 2008). Previous risk awareness and perception studies have mostly been based on household surveys and found that (volcanic) risk is perceived differently among local scientists (at the University of Buea and the Cameroon Geological Survey) and the local population (Njome et al. 2010; Pannaccione Apa et al. 2012). Atanga et al. $(2009,2010)$ assessed the health risks of Mount Cameroon volcanic ash, and studied mitigation approaches by community members and frontline workers. The ability or inability of the exposed population to cope with risk has not been assessed in detail, nor have the preparedness and mitigation efforts from the local authorities been evaluated.

Following the Mount Cameroon eruption crises in 1999 and 2000, a 5-year (2008-2013) bilateral capacity building project for geohazard research and management was established by the Flemish Interuniversity Council-University Development Cooperation (VLIR UOS, Belgium) between the University of Buea (Cameroon) and Ghent University (Belgium). The scientists from the University of Buea had limited training in geohazard crisis management as well as a shortage of laboratory facilities. The societal objectives were to raise the capacity and preparedness of the University of Buea, the local authorities and the population to improve the geohazard management strategy to the benefit of all relevant stakeholders. Scientific objectives included constraining the spatial distribution of lava flows (Wantim et al. 2011, 2013a, b) and landslide susceptibility (Che et al. 2012b, 2013). Another objective was to improve research and training capacity for monitoring volcanic and landslide hazards at the University of Buea.

Various activities were aimed at improving risk awareness and communication efficiency and were performed throughout the project (Fig. 2). All of these activities focused on volcanic hazards relevant to Mount Cameroon, as well as on landslide and crater lake hazards. Two stakeholder workshops were organised to raise awareness about geohazards and to discuss crisis management and early warning systems. The participants represented the Universities of Buea and Ghent, national research institutions, government services, municipal authorities, civil society (NGOs, CSOs, and farmer groups), and traditional authorities (e.g. village chiefs). The second workshop was concluded with the elaboration of various information billboards. Their content and design was informed by discussions 


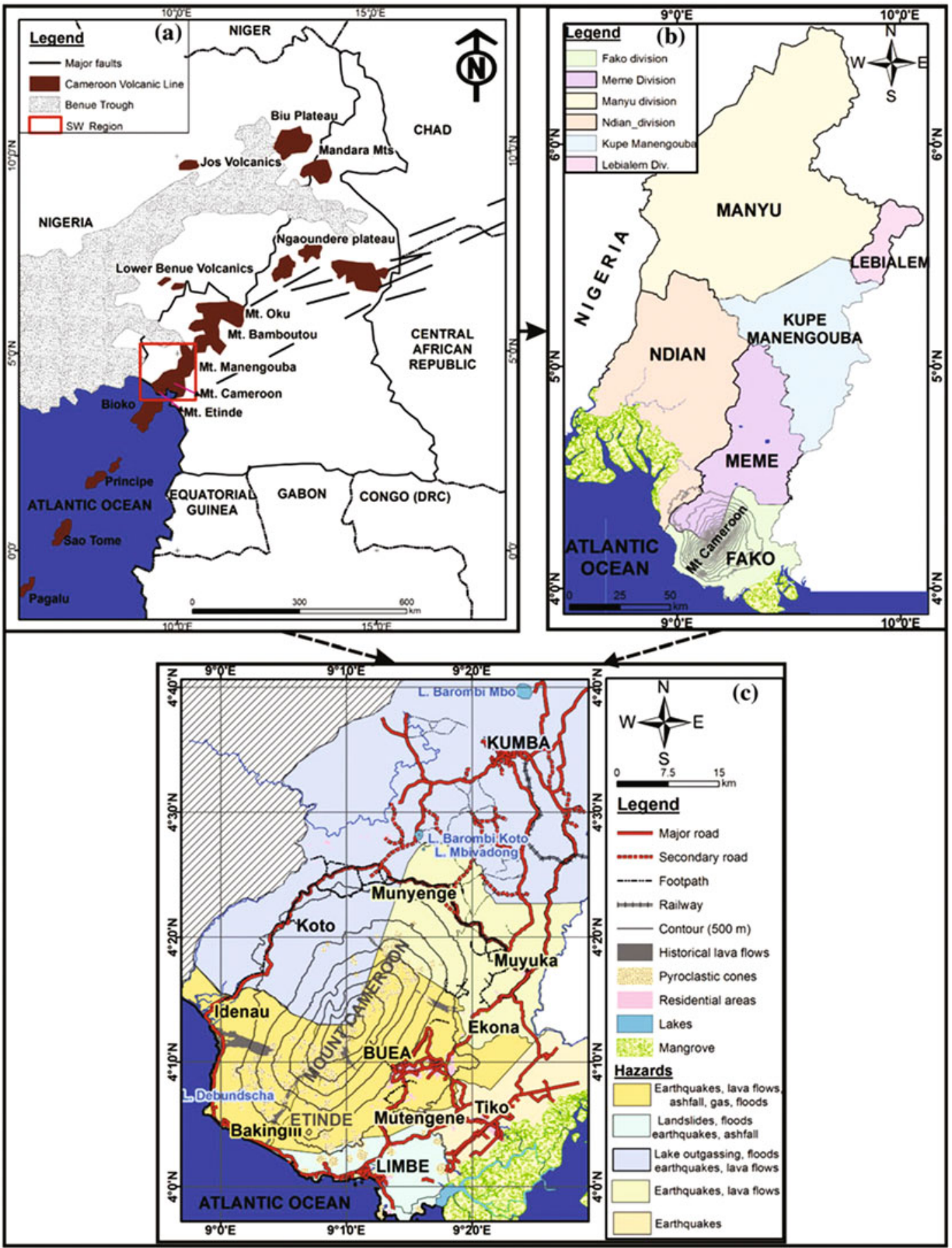

Fig. 1 a Location of the Cameroon Volcanic Line in West Africa; b Mount Cameroon with the surroundinglargely Anglophone - administrative divisions; c Mount
Cameroon with main settlements at risk of a variety of natural hazards, including volcanic eruptions, landslides, floods, crater lake outgassing and earthquakes 

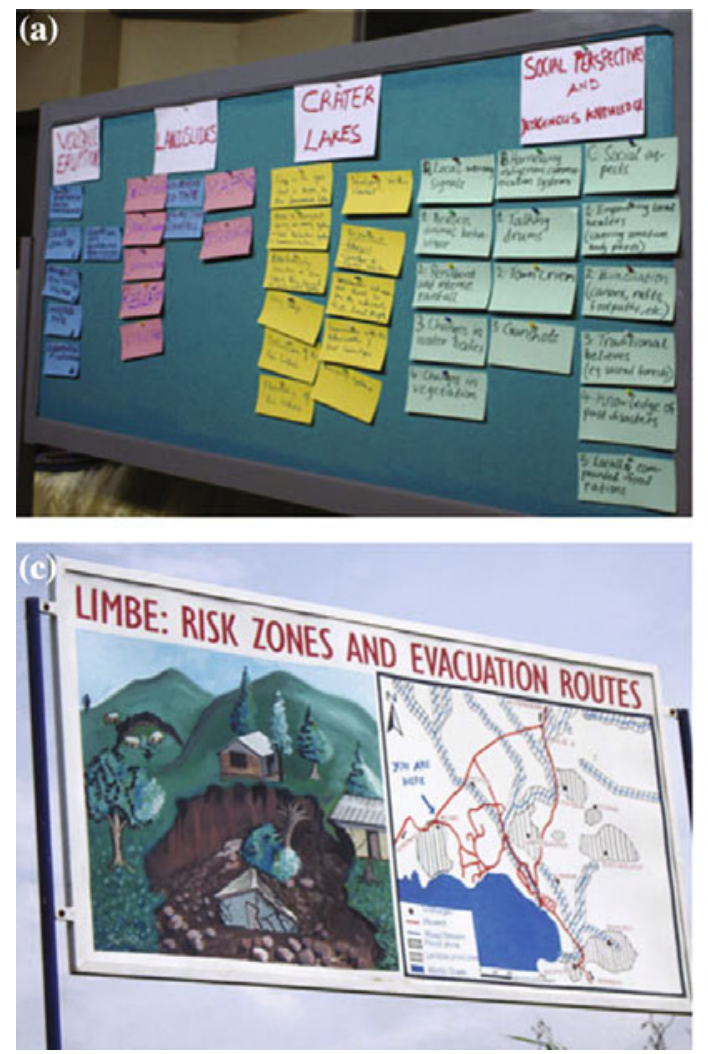

Fig. 2 Photos illustrating awareness-raising actions undertaken as part of the 5-year VLIR-UOS project. a stakeholder workshop discussion session; b billboard in Buea illustrating volcanic hazards and risks; $\mathbf{c}$ billboard in

following introductions by the local and Belgian specialists of various geohazards and related (health) risks. For instance, it was decided that the morphology of the volcano drawn on the billboard (by a local artist from Buea) should represent the realistic view at the specific location where the billboard would be put in place. Further awareness-raising actions such as training of teachers were conducted in various schools and in front of the billboards. Additional sensitisation activities took place in villages and were led by local team members specialised in volcanic hazard and related health issues. A dedicated activity took place on International Women's Day (8th March) which is widely celebrated in Cameroon, and which provided the opportunity to reach a significant proportion of the population. Radio programs were found to be
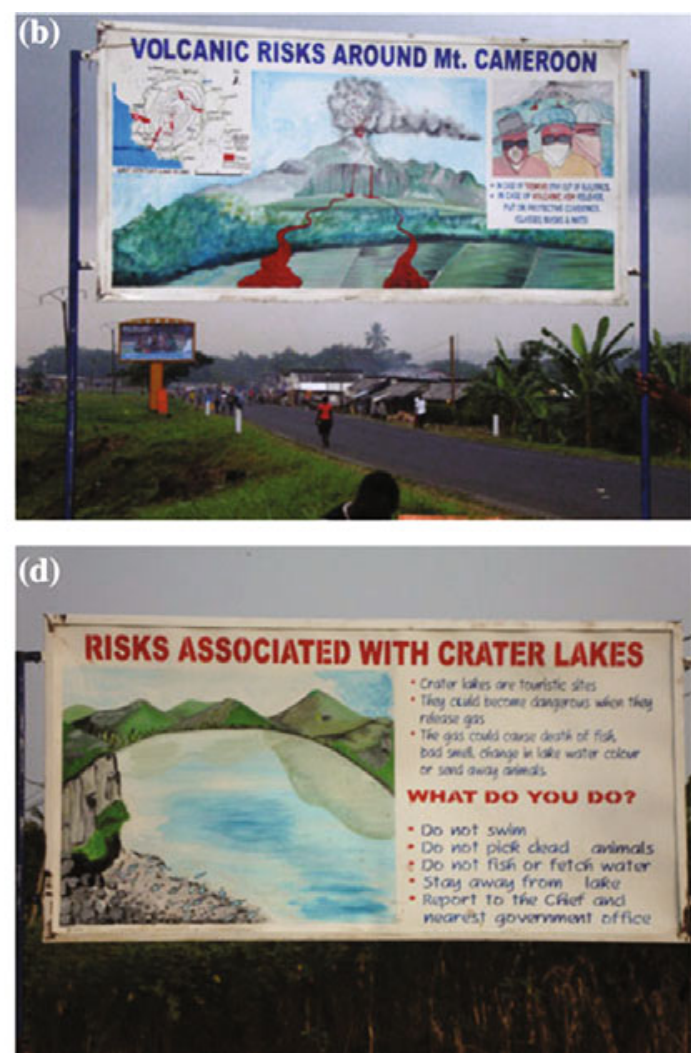

Limbe illustrating landslide hazards and risks; $\mathbf{d}$ billboard in Kumba illustrating crater lake outgassing hazards and risks

a successful communication tool as they are very popular amongst the local population, and typically reach a much larger proportion of the population than the written press. Further training initiatives targeted at the press were undertaken to specifically improve communication efficiency and address risk awareness amongst the local population.

\subsection{Focus Group Discussions}

The merit of social studies on risks related to natural hazards lies in the fact that they are able to elicit information which can supplement results of purely scientific studies (e.g. hazard maps) and provide insights on how the population perceives risk (Atanga et al. 2010; Njome 
et al. 2010). The participation of communities has been found to be essential in identifying ways to mitigate risks (e.g. Gaillard and Dibben 2008). One way to interact with a community and collect data on the different aspects of the risk management cycle (preparedness, response, recovery, mitigation) is by means of focus group discussions (FGDs; Bohnsack 2004).

The FGD approach provides an open and interactive discussion forum, unlike a structured questionnaire, and is therefore particularly useful to obtain an in-depth understanding because discussions can range from simple to abstract ideas on a specific topic. In such circumstances all the relevant information can be discussed to the point of saturation. Moreover, it has been found that FGD participants tend to speak more freely and with more detail compared to a standard interview or structured questionnaire, which is believed to limit the extent to which people can express their own views (Mercer and Kelman 2010). The participants should be a cross-section of a community including both literate and illiterate people. FGDs provide a qualitative research tool for the scientists, but are particularly meaningful for the stakeholders as well, since they provide a platform for the participants to meet, interact, explore and cross-examine the matter at hand.

To understand how the local communities in the Mount Cameroon area are prepared for and cope with a variety of potential natural hazards, three FGDs were held at the city councils of three strategically selected towns. Each of these towns is prone to certain types of natural hazards (Fig. 1): (1) Buea (ca. 150,000 inhabitants) is located at the $\mathrm{E}$ foot of the volcano and has experienced ash fall from 20th century eruptions and significant earthquake damage in 1995; (2) Kumba (ca. 200,000 inhabitants) is located to the NE, too far to be directly impacted by an eruption but is downhill and downstream of a crater lake with the potential to outgas, and which provides the main water supply to the town; it is also prone to landslides and earthquakes; (3) Limbe (ca. 95,000 inhabitants; invited participants from Limbe 1 council) is located near the SE coast with a high risk of lava flow invasion (Favalli et al. 2011) and has experienced multiple flooding and landslide events in recent decades (Ayonghe et al. 2004; Che et al. 2011). The risk imposed by floods and landslides is enhanced by unregulated building practices (Che et al. 2012b). The FGDs were organised in May 2010 as part of the risk assessment part of the VLIR UOS project. Between 4 and 6 participants were selected from each city council (Wilkinson 2004). Their level of responsibility within the council varied from councillor with or without technical education, to engineer, traditional ruler, local chief, and mayor.

In this study four cardinal points (preparedness, response, recovery and reconstruction) guided the FGDs (Fothergill 1996). The aim of the discussions was to collect the views of the councillors on each of the four points, for risks related to volcanic eruptions, landslides, floods and crater lakes. Each discussion began with a general presentation by a scientist on natural hazards which reminded the participants of some definitions such as hazard versus risk, using a simple every-day example (e.g. the occurrence of rain = hazard; getting wet = risk; carrying an umbrella $=$ mitigating the risk), in order to guide the discussion process. It was established that, prior to and throughout the discussion, the concept of hazard versus risk was understood by all participants in the three cities. A local scientist further introduced the topic and moderated the conversation with the help of a predefined structure (Appendix). Volcanic, landslide or crater lake risks were not specifically mentioned or given as an example in the introduction, in order to avoid biased discussions. Notes were taken by another local scientist. The discussions were carried out in English, the local language mastered and preferred by all participants and researchers, and all discussions were audio- and video-recorded, and photographs were taken, all with consent from the participants. During the discussion it was ensured that the participants valued their role as representatives of their communities, and that they were able to speak on behalf of their community members. The discussion was free as all the participants were at the 
same level in discussing with researchers. Each discussion lasted between one to three hours, without predefined time limits.

\section{Results}

The councils of the three main cities around Mount Cameroon where the FGDs took place all have slightly different approaches to the preparation and response to hazards, and post-event reconstruction. Prominent and recurring themes are highlighted in Table 1, following the general structure (Appendix), and further discussed below.

\subsection{Hazard and Risk Perception and Preparedness}

The first section of the FGDs dealt with preparedness to natural hazards (Table 1). The different types of natural hazards constituting a threat in each area were well perceived except in Kumba. The outgassing of the crater lake was not mentioned as a potential hazard/risk. Floods and landslides were extensively discussed: this was not surprising given the high frequency of occurrence of these events.

In Buea, the participants expressed that they were "at the foot of an active volcanic mountain and the mountain can erupt anytime" and that

Table 1 Schematic overview of responses in each city council to each question of the FGD. Identities of respondents to specific questions have been omitted. The full details of each question can be found in Appendix. Some answers to questions appeared in discussions after subsequent questions, e.g. some specific hazard types (question A1a) were only mentioned in a discussion on associated risks (question A1c). Transcripts of the discussions are available upon request

\begin{tabular}{l|l|l|l|l}
\hline \multicolumn{2}{l|}{ Question } & City & \\
\hline Code & Theme & Buea & Kumba & Limbe 1 \\
\hline
\end{tabular}

Aspect A: Preparedness

\begin{tabular}{|c|c|c|c|c|}
\hline \multicolumn{5}{|c|}{ A1-Natural hazards that could constitute risk to the municipality } \\
\hline Ala & Types of hazard & $\begin{array}{l}\text { - Volcanic eruption } \\
\text { - Tremors } \\
\text { - Landslides } \\
\text { - Floods }\end{array}$ & $\begin{array}{l}\text { - Landslides } \\
\text { - Floods } \\
\text { - Thunderstorms } \\
\text { Specific locations mentioned } \\
\text { by name }\end{array}$ & $\begin{array}{l}\text { - Floods } \\
\text { - Landslides } \\
\text { - Volcanic eruption } \\
\text { - Tsunami } \\
\text { - Coastal } \\
\text { subsidence/erosion }\end{array}$ \\
\hline $\mathrm{A} 1 \mathrm{~b}$ & Causes of hazards & $\begin{array}{l}\text { - Landslide: heavy rainfall } \\
\text { - Floods: blocked gutters }\end{array}$ & $\begin{array}{l}\text { - Human activity: } \\
\text { construction on river } \\
\text { embankments: narrowed } \\
\text { water courses } \\
\rightarrow \text { Floods } \\
\text { - Human activity: refuse } \\
\text { disposal in rivers } \\
\rightarrow \text { Floods } \\
\text { - Human activity: } \\
\text { deforestation } \\
\rightarrow \text { Landslides } \\
\text { - Human activity: reclaiming } \\
\text { marshy areas } \\
\text { - Heavy rainfall } \\
\rightarrow \text { Floods }\end{array}$ & $\begin{array}{l}\text { - Topography: Limbe } \\
\text { surrounded by hills } \\
\text { - Topography: parts of } \\
\text { Limbe below sea level } \\
\text { - Human activity: } \\
\text { deforestation, erosion } \\
\rightarrow \text { Landslides } \\
\text { - Human activity: } \\
\text { uncontrolled } \\
\text { urbanisation, blocking } \\
\text { natural waterways } \\
\rightarrow \text { Floods }\end{array}$ \\
\hline A1c & Associated risks & $\begin{array}{l}\text { - Building in mapped } \\
\text { (landslide/flood) disaster } \\
\text { zones } \\
\text { - Damaged to houses due to } \\
\text { vibration during an } \\
\text { eruption }\end{array}$ & $\begin{array}{l}\text { - Landslides: buildings on } \\
\text { top of hills } \\
\text { - Flooding (houses): } \\
\text { transport of waste, risk of } \\
\text { diseases }\end{array}$ & $\begin{array}{l}\text { - Lost material property } \\
\text { due to uncontrolled } \\
\text { urbanisation } \\
\text { - Coastal subsidence due to } \\
\text { tremors during volcanic } \\
\text { eruption }\end{array}$ \\
\hline
\end{tabular}


Table 1 (continued)

\begin{tabular}{|c|c|c|c|c|}
\hline \multicolumn{2}{|c|}{ Question } & \multicolumn{3}{|l|}{ City } \\
\hline Code & Theme & Buea & Kumba & Limbe 1 \\
\hline & & & $\begin{array}{l}\text { - Clearing debris from the } \\
\text { roads after landslide } \\
\text { constitutes a risk in itself } \\
\text { - Lake Barumbi linked to } \\
\text { Mount Cameroon: } \\
\text { eruption affecting the lake } \\
\text { water, which provides all } \\
\text { the water supply for the } \\
\text { town through the } \\
\text { Mabungisse river at high } \\
\text { risk of flooding }\end{array}$ & $\begin{array}{l}\text { - Coastal erosion: gradual } \\
\text { inland movement of the } \\
\text { coastline threatening the } \\
\text { town } \\
\text { - Heavy rainfall - water } \\
\text { table rising above surface } \\
\text { in some places }\end{array}$ \\
\hline A1d & Warning signs & None known & $\begin{array}{l}\text { - Landslides: cracks (lines) } \\
\text { opening up in the soil } \\
\text { - Flood-prone zones (near } \\
\text { meanders): heavy rain, } \\
\text { rising water levels, strange } \\
\text { animal behaviour } \\
\rightarrow \text { People will move already } \\
\text { once the water gets to a } \\
\text { certain level }\end{array}$ & $\begin{array}{l}\text { - Landslides, floods: } \\
\text { several days of } \\
\text { consecutive rain } \\
\text { - Eruptions: only observed } \\
\text { (fire, volcanic ash) when } \\
\text { already taking place } \\
\text { - Tremors } \\
\text { - Vibrations sometimes } \\
\text { before, during or after } \\
\text { eruptions }\end{array}$ \\
\hline Ale & $\begin{array}{l}\text { Source of } \\
\text { information }\end{array}$ & $\begin{array}{l}\text { - Close collaboration with } \\
\text { Ministry of Scientific } \\
\text { Research } \\
\text { - Scientists at University of } \\
\text { Buea } \\
\text { - Community knows about } \\
\text { the volcano, but not about } \\
\text { floods }\end{array}$ & $\begin{array}{l}\text { - Presence of town planners } \\
\text { carrying out routine checks } \\
\text { - Interaction with the people } \\
\text { —who may base } \\
\text { themselves on strange } \\
\text { animal behaviour } \\
\text { - Ministries: } \\
\text { - Environment } \\
\text { - Hygiene and Sanitation } \\
\text { - Mines, Water Resources } \\
\text { and Energy }\end{array}$ & $\begin{array}{l}\text { - Scientists } \\
\text { - Geological Research } \\
\text { Centre } \\
\text { - Surveillance system in } \\
\text { place around the } \\
\text { mountain }\end{array}$ \\
\hline
\end{tabular}

\section{A2-Schemes in preparation for disasters}

Scheme in preparation for disasters
- City council takes responsibility in case of an event, but no means are reserved specifically to prepare for disasters

- Many councillors unaware of potential disasters

- Spending scheme of council budget needs to be voted on - money more likely reserved for critical infrastructure than for disaster prevention, due to unawareness of councillors
- Areas declared as risk zones (landslide-prone, regularly flooding): no building permits issued

- Investigations in certain areas at regular risk as to what causes the problems

- Regular (yearly) dredging of specific areas at high risk of flooding

- River course too narrow - Surrounding vegetation too compact

- Refuse blocking the water flow

- Some budget set aside for crisis management

- Plans to terrace Ntoko Hill, at high risk of landslides

- Most actions happen spontaneously, in case of an event. Preparation measures not systematically documented by the council.

Documentation may exist
None

(continued) 
Table 1 (continued)

\begin{tabular}{|c|c|c|c|c|}
\hline \multicolumn{2}{|c|}{ Question } & \multicolumn{3}{|l|}{ City } \\
\hline Code & Theme & Buea & Kumba & Limbe 1 \\
\hline & & & $\begin{array}{l}\text { in the form of minutes of } \\
\text { meetings. } \\
\text { - Buildings in designated } \\
\text { high-risk zones marked to } \\
\text { be demolished }\end{array}$ & \\
\hline A2a & $\begin{array}{l}\text { Regulations towards } \\
\text { reducing risk }\end{array}$ & $\begin{array}{l}\text { - Laws/regulations exist, but } \\
\text { not implemented due to } \\
\text { lack of funding and more } \\
\text { pressing basic needs of } \\
\text { population }\end{array}$ & $\begin{array}{l}\text { Administrative levels: } \\
\text { - Government delegate or } \\
\text { Mayor - will authorise } \\
\text { budget allocation and } \\
\text { action to take, based on } \\
\text { technical reports written by } \\
\text { responsible departments } \\
\text { - Council to follow advise } \\
\text { To approve building permits, } \\
\text { the council departments in } \\
\text { charge have to go and see } \\
\text { what kind of } \\
\text { area/environment/building } \\
\text { the permit is being asked for. }\end{array}$ & $\begin{array}{l}\text { - Building regulations, e.g. } \\
\text { certain distance from } \\
\text { stream banks } \\
\text { - Certain areas declared as } \\
\text { risk zones by the } \\
\text { government } \\
\text { These regulations are not } \\
\text { respected by people }\end{array}$ \\
\hline $\mathrm{A} 2 \mathrm{~b}$ & $\begin{array}{l}\text { Unit in charge at } \\
\text { municipality level }\end{array}$ & $\begin{array}{l}\text { - Specific committee in } \\
\text { charge of community } \\
\text { protection } \\
\text { - Close collaboration with } \\
\text { the Mayor, Division } \\
\text { Officer, Governor and } \\
\text { Ministry in case of an } \\
\text { event }\end{array}$ & $\begin{array}{l}\text { Departments of Town } \\
\text { Planning and Hygiene and } \\
\text { Sanitation: both in charge of } \\
\text { approving building permits }\end{array}$ & $\begin{array}{l}\text { - Town Planning Services, } \\
\text { in collaboration with } \\
\text { related government } \\
\text { services } \\
\text { - Council due to take more } \\
\text { responsibility and } \\
\text { decisions related } \\
\text { preparedness } \\
\text { (decentralisation policy) }\end{array}$ \\
\hline $\mathrm{A} 2 \mathrm{c}$ & $\begin{array}{l}\text { Facilities to manage } \\
\text { risk }\end{array}$ & $\begin{array}{l}\text { - Bulldozer to clear roads } \\
\text { and gutters in case of } \\
\text { floods } \\
\text { - No other means }\end{array}$ & $\begin{array}{l}\text { - Financial resources for } \\
\text { major facilities (e.g. } \\
\text { dredging works) put at } \\
\text { disposal after authorisation } \\
\text { by Government Delegate } \\
\text { or Mayor based on } \\
\text { technical reports } \\
\text { - Basic facilities (equipment, } \\
\text { transport, manpower) at } \\
\text { disposal of Hygiene } \\
\text { service for burials if } \\
\text { needed }\end{array}$ & $\begin{array}{l}\text { - First aid provided when } \\
\text { anything happens } \\
\text { - Nothing else-a crisis } \\
\text { commission will be } \\
\text { created in case of an } \\
\text { event }\end{array}$ \\
\hline
\end{tabular}

A3-Warning systems

\begin{tabular}{|c|c|c|c|c|}
\hline A3a & $\begin{array}{l}\text { Warning systems in } \\
\text { place in case of an } \\
\text { emergency }\end{array}$ & $\begin{array}{l}\text { - None } \\
\text { - (billboards explaining } \\
\text { natural hazards in a more } \\
\text { general way - not for } \\
\text { emergencies) }\end{array}$ & $\begin{array}{l}\text { - Local radio stations-paid } \\
\text { on monthly basis to pass } \\
\text { on council's } \\
\text { announcements in an } \\
\text { interactive programme } \\
\text { where people can also call } \\
\text { themselves and ask } \\
\text { questions } \\
\text { - Local churches } \\
\text { - Letters to village chiefs, } \\
\text { local quarter heads who } \\
\text { will announce the } \\
\text { information to their people } \\
\text { - Meeting houses of } \\
\text { traditional, tribal groups }\end{array}$ & $\begin{array}{l}\text { - None } \\
\text { - People tend to rely on } \\
\text { themselves, helping each } \\
\text { other } \\
\text { - Chiefs and } \\
\text { Mayor/Council in contact } \\
\text { with each other-system } \\
\text { filters down to village } \\
\text { level }\end{array}$ \\
\hline
\end{tabular}


Table 1 (continued)

\begin{tabular}{|c|c|c|c|c|}
\hline \multicolumn{2}{|c|}{ Question } & \multicolumn{3}{|l|}{ City } \\
\hline Code & Theme & Buea & Kumba & Limbe 1 \\
\hline $\mathrm{A} 3 \mathrm{~b}$ & $\begin{array}{l}\text { Population informed } \\
\text { about these systems? }\end{array}$ & N/A & $\begin{array}{l}\text { - Yes } \\
\text { - Communication channels } \\
\text { evaluated through } \\
\text { population's response, } \\
\text { revised where needed }\end{array}$ & N/A \\
\hline \multirow[t]{2}{*}{$\mathrm{A} 3 \mathrm{c}$} & $\begin{array}{l}\text { (Other) possible } \\
\text { tools to enhance } \\
\text { warning efficacy }\end{array}$ & $\begin{array}{l}\text { - Monitoring equipment on } \\
\text { the volcano (was there } \\
\text { before, but was taken } \\
\text { away) }\end{array}$ & $\begin{array}{l}\text { - Information boards with } \\
\text { warning signals identifying } \\
\text { high-risk zones, informing } \\
\text { people they should not buy } \\
\text { land or construct in those } \\
\text { areas. These kinds of } \\
\text { boards should be protected } \\
\text { from demolition/removal }\end{array}$ & $\begin{array}{l}\text { - Aspect of spontaneous } \\
\text { solidarity raised again } \\
\text { - Mobile phones to } \\
\text { communicate between } \\
\text { chiefs, Mayor and } \\
\text { councillors }\end{array}$ \\
\hline & Remarks & $\begin{array}{l}\text { Demand for information } \\
\text { seminars at the council and } \\
\text { community levels to create } \\
\text { more awareness. At the } \\
\text { council level, this could lead } \\
\text { to more budgets being } \\
\text { allocated to risk mitigation. }\end{array}$ & & \\
\hline
\end{tabular}

Aspect B: Response

\section{B1-Risk communication to the population}

\begin{tabular}{|l|l|l}
\hline B1 & $\begin{array}{l}\text { Means of } \\
\text { communicating risk } \\
\text { to population }\end{array}$ & $\begin{array}{l}- \text { Media } \\
- \text { Intervention unit going } \\
\text { door to door to talk to } \\
\text { people }\end{array}$ \\
\hline B1a & $\begin{array}{l}\text { Anticipated } \\
\text { response of } \\
\text { population to }\end{array}$ & $\begin{array}{l}\text { Some people are stubborn } \\
\text { to evacuate (law } \\
\text { enforcement used) }\end{array}$ \\
\hline Warnings
\end{tabular}

warnings

\section{- Radio}

- Churches

- Quarter heads

- Meeting houses

All communication to and

from the council passes

through the Government

Delegate

- People following warnings and moving away, especially for short-term hazards like floods

- In other places, e.g. Ntoko Hill at high risk for landslides, people tend to be more adamant and stay. Usually less than $10 \%$ of the people.

- About $10 \%$ of people have abandoned their houses permanently (usually forced by nature, e.g. permanent flooding)

- Some people try to actively prevent floods by constructing dams to deviate the water

(Need to be careful with forced action because of human rights action groups)
- Supervisory authority (administration) takes control

- Going round villages, using e.g. whistle and bell to alert people

- They follow instructions on what has to be done

- Spontaneous community response 
Table 1 (continued)

\begin{tabular}{|c|c|c|c|c|}
\hline \multicolumn{2}{|c|}{ Question } & \multicolumn{3}{|l|}{ City } \\
\hline Code & Theme & Buea & Kumba & Limbe 1 \\
\hline $\mathrm{B} 1 \mathrm{~b}$ & Language used & $\begin{array}{l}\text { - Pidgin english } \\
\text { - Local dialect } \\
\text { Depending on the area } \\
\text { affected }\end{array}$ & $\begin{array}{l}\text { - Official (written) } \\
\text { communication all in } \\
\text { English } \\
\text { - Local delivery of the } \\
\text { message usually in Pidgin } \\
\text { English or local dialect, } \\
\text { depending on tribal group } \\
\text { - Signs (e.g. red paint } \\
\text { marks), summon papers or } \\
\text { abatement notices used to } \\
\text { call on people and invite } \\
\text { them to discuss building } \\
\text { location }\end{array}$ & Pidgin english \\
\hline $\mathrm{B} 1 \mathrm{c}$ & $\begin{array}{l}\text { Success of } \\
\text { communication } \\
\text { evaluated }\end{array}$ & $\begin{array}{l}\text { - Go back and ensure people } \\
\text { are safe } \\
\text { - Council meeting discussing } \\
\text { what has been done }\end{array}$ & $\begin{array}{l}\text { Evaluated from the level of } \\
\text { response }\end{array}$ & Message gets across \\
\hline \multicolumn{5}{|c|}{ B2-Risk communication to higher authorities } \\
\hline B2 & $\begin{array}{l}\text { Means of } \\
\text { communicating risk } \\
\text { to higher authorities }\end{array}$ & $\begin{array}{l}\text { Council workers on site } \\
\text { informing Mayor, who will } \\
\text { then call the appropriate } \\
\text { delegate at the Ministry or } \\
\text { other services if more } \\
\text { intervention is needed }\end{array}$ & $\begin{array}{l}\text { - Mostly it is the higher } \\
\text { authorities communicating } \\
\text { risk to the council. The } \\
\text { council depends purely on } \\
\text { the population to report, } \\
\text { but the government seems } \\
\text { to have better mechanisms } \\
\text { in place } \\
\text { - Phone calls (for } \\
\text { emergencies) and/or } \\
\text { written letter to subdivision } \\
\text { officer, not supported by } \\
\text { documents (spontaneous } \\
\text { action) } \\
\text { - Final report made by the } \\
\text { council after the events }\end{array}$ & $\begin{array}{l}\text { - Phone calls } \\
\text { - Administrative writings } \\
\text { - Crisis meetings }\end{array}$ \\
\hline
\end{tabular}

\section{B3-Risk communication to scientists}

\begin{tabular}{|c|c|c|c|c|}
\hline B3 & $\begin{array}{l}\text { Liaison with } \\
\text { researchers/scientists }\end{array}$ & $\begin{array}{l}\text { First ones contacted as they } \\
\text { are best placed to advise } \\
\text { what to do }\end{array}$ & $\begin{array}{l}\text { - One scientist once wrote to } \\
\text { the council to warn about } \\
\text { rising water levels at } \\
\text { certain river. The governor } \\
\text { set up a small commission } \\
\text { to go out in the field and } \\
\text { investigate } \\
\text { - NGOs writing advisory } \\
\text { reports on what can be } \\
\text { done in terms of } \\
\text { prevention, e.g. on Ntoko } \\
\text { Hill } \\
\text { - No set structure to interact } \\
\text { with scientists and } \\
\text { researchers } \\
\text { - It is difficult to know who } \\
\text { the scientists are, where } \\
\text { they are based and what } \\
\text { they are doing. The council } \\
\text { expects the scientists to } \\
\text { come to them and is then } \\
\text { very willing to collaborate }\end{array}$ & Cordial relationship \\
\hline
\end{tabular}


Table 1 (continued)

\begin{tabular}{|c|c|c|c|c|}
\hline \multicolumn{2}{|c|}{ Question } & \multicolumn{3}{|l|}{ City } \\
\hline Code & Theme & Buea & Kumba & Limbe 1 \\
\hline \multicolumn{5}{|c|}{ B4-Immediate response } \\
\hline B4 & $\begin{array}{l}\text { Immediate response } \\
\text { in case of a crisis }\end{array}$ & $\begin{array}{l}\text { - Observe on site } \\
\text { - Look for means to evacuate } \\
\text { people if needed, in } \\
\text { collaboration with law } \\
\text { enforcement officers } \\
\text { - Contact media } \\
\text { - Assistance with material or } \\
\text { medical needs } \\
\text { - Floods: open waterways } \\
\text { and remove debris using } \\
\text { bulldozer }\end{array}$ & $\begin{array}{l}\text { - Go down to site and } \\
\text { evaluate the degree of risk, } \\
\text { the damage, etc. } \\
\text { - Decide what can be done to } \\
\text { support victims, e.g. } \\
\text { assistance in burials } \\
\text { - Provide help on the spot, } \\
\text { e.g. trying to save people } \\
\text { in danger } \\
\text { - People themselves will also } \\
\text { assist in relieving the } \\
\text { situation } \\
\text { - Ensure security to prevent } \\
\text { looting } \\
\text { - Action depends on the } \\
\text { situation }\end{array}$ & $\begin{array}{l}\text { - Go observe on site } \\
\text { - People evacuated to safe } \\
\text { place } \\
\text { - Material and financial } \\
\text { assistance } \\
\text { - Population also assists }\end{array}$ \\
\hline \multicolumn{5}{|c|}{ B5/B6-Last crisis } \\
\hline B5 & $\begin{array}{l}\text { Last crisis } \\
\text { experienced }\end{array}$ & $\begin{array}{l}\text { Flood at the hospital } 2 \text { years } \\
\text { ago (2009) }\end{array}$ & $\begin{array}{l}\text { - Thunder strike about } \\
1 \text { month ago } \\
\text { - Storm yesterday } \\
\text { - Flood } \\
\text { - Last eruption (Bakingli) } \\
\text { affected the lake at the } \\
\text { source of the Mabungisse } \\
\text { river }\end{array}$ & $\begin{array}{l}\text { - Frequent floods of } \\
\text { different scales } \\
-2001 \text { floods most recent } \\
\text { major crisis taking lives } \\
\text { - } 2009 \text { landslide blocking } \\
\text { the road }\end{array}$ \\
\hline B6 & Impacts of last crisis & $\begin{array}{l}\text { - Damage to houses } \\
\text { - Damage to hospital fence } \\
\text { - Road to hospital blocked }\end{array}$ & $\begin{array}{l}\text { - Yesterday's storm: } \\
\text { - Roof collapses } \\
\text { - Damage to crops } \\
\text { - Floods: } \\
\text { - people displaced } \\
\text { - loss of property } \\
\text { - loss of lives } \\
\text { - reduced farmland (limited } \\
\text { impact) } \\
\text { - disease outbreaks } \\
\text { (diarrhoea, malaria) } \\
\text { - People uncomfortable } \\
\text { living near place where } \\
\text { decomposing bodies are } \\
\text { buried (e.g. corpses only } \\
\text { recovered from floods after } \\
\text { a few days) }\end{array}$ & $\begin{array}{l}\text { - Sketchy and unbalanced } \\
\text { documentation of events } \\
\text { - Loss of lives, property } \\
\text { - People displaced, some } \\
\text { people even moved to } \\
\text { America } \\
\text { - Depression, traumas } \\
\text { - Financial burden } \\
\text { - Thieves taking advantage }\end{array}$ \\
\hline
\end{tabular}

Aspect C: Recovery

\section{C1-Recovery strategy}

\begin{tabular}{|c|c|c|c|c|}
\hline $\mathrm{C} 1$ & $\begin{array}{l}\text { Council strategy to } \\
\text { help people } \\
\text { overcome basic } \\
\text { problems }\end{array}$ & $\begin{array}{l}\text { - Look for temporary } \\
\text { housing for evacuees } \\
\text { - Delegation of Health to } \\
\text { assess potential of disease } \\
\text { outbreak } \\
\text { - Extraordinary council } \\
\text { session to discuss budget } \\
\text { reallocation in case people } \\
\text { need financial help to } \\
\text { relocate or rebuild houses }\end{array}$ & $\begin{array}{l}\text { - Council needs formal } \\
\text { request for assistance } \\
\text { before it can act, e.g. from } \\
\text { health services requesting } \\
\text { extra vaccinations, or from } \\
\text { the population } \\
\text { - People often afraid to come } \\
\text { to the council if they were } \\
\text { living in "no-go areas" }\end{array}$ & None \\
\hline
\end{tabular}


Table 1 (continued)

\begin{tabular}{l|l|l|l|l}
\hline Question & City & \multicolumn{2}{l}{} \\
\hline Code & Theme & Buea & Kumba & Limbe 1 \\
\hline C2 & $\begin{array}{l}\text { Strategy used in last } \\
\text { crisis? }\end{array}$ & - Yes & N/A & $\begin{array}{l}\text { Other organisations } \\
\text { (SONARA) came in and } \\
\text { built houses to assist } \\
\text { people, but in insufficient } \\
\text { amounts. Those buildings } \\
\text { are now used as a school- } \\
\text { council was consulted at } \\
\text { first but could not intervene }\end{array}$ \\
\hline
\end{tabular}

Aspect D: Mitigation

D1-Policy measures for long-lasting solutions to risk

\begin{tabular}{|c|c|c|c|c|}
\hline D1 & Policy & $\begin{array}{l}\text { Areas indicated where } \\
\text { construction is not allowed }\end{array}$ & $\begin{array}{l}\text { - Contracts with dredger } \\
\text { - No written policy } \\
\text { documents guiding actions, } \\
\text { all actions spontaneous } \\
\text { - Budget is available from } \\
\text { the government for } \\
\text { councillors to attend } \\
\text { seminars on risk } \\
\text { management } \\
\text { Proposals for the full } \\
\text { dredging of a high-risk river, } \\
\text { or terracing of a high-risk } \\
\text { hill, but without financial } \\
\text { means and resources, these } \\
\text { proposals will not convert } \\
\text { into policy }\end{array}$ & $\begin{array}{l}\text { - Areas designated as risk } \\
\text { zones } \\
\text { - Relocation of people } \\
\text { living in risk zones }\end{array}$ \\
\hline D1a & Source of policy & Government & $\begin{array}{l}\text { Government policy on risk } \\
\text { management, none at the } \\
\text { level of the council }\end{array}$ & $\begin{array}{l}\text { Ministry of Town Planning } \\
\text { and Housing }\end{array}$ \\
\hline \multicolumn{5}{|c|}{ D2-Strategies to back up policy } \\
\hline & & Keep waterways open & $\begin{array}{l}\text { - Marking houses for } \\
\text { demolition } \\
\text { - Regular (small-scale) } \\
\text { dredging }\end{array}$ & None \\
\hline
\end{tabular}

D3-Implementation of strategy

\section{N/A}

- Regular dredging of river at high risk of flooding

- Clearing areas

- Marking houses of demolition
- Sensitisation and education

- Encouraging people to stop farming but plant trees in risk areas

- Stringent observance of building rules and regulations

- People not actually relocated

\section{D4-Other strategies and actions envisaged by the municipality}

\begin{tabular}{l|l|l|l|l}
\hline D4 $\begin{array}{l}\text { Other strategies that } \\
\text { could help }\end{array}$ & $\begin{array}{c}\text { - Appropriate monitoring of } \\
\text { seismic or volcanic activity } \\
- \text { Sensitising communities in } \\
\text { the form of seminars, to } \\
\text { educate the population } \\
\text { about the types of risks, } \\
\text { and point out risky areas } \\
\text { - Funding alone will not be } \\
\text { sufficient }\end{array}$ & $\begin{array}{l}\text { Information seminars for } \\
\text { the council }\end{array}$ & $\begin{array}{l}\text { - Strategic planning } \\
- \text { Relocation of people } \\
\text { away from risk zones } \\
\text { - Land now used for } \\
\text { plantations freed for } \\
\text { people to live; plantations } \\
\text { moved to the forest }\end{array}$ \\
& & $\begin{array}{l}\text { - Decentralisation, more } \\
\text { autonomy and power to } \\
\text { the councils }\end{array}$
\end{tabular}


"the community knows much about the volcanic mountain but does not know much about the flood". In Limbe, volcanic eruptions were also mentioned as a potential hazard, but in the other two towns, eruptions did not seem to be considered as a serious hazard. In Limbe it was further noted that coastal subsidence has occurred in the past due to tremors associated with an eruption. These tremors are felt only sometimes before an eruption and taken as a warning signal. Ateba et al. (2009) observed that the tremors are concomitant to an eruption. Although participants easily identified the cause and warning signs of landslides and floods, they did not mention any cause for earthquake and volcanic events nor did they know of warning signs except for tremors.

Heavy rainfall was considered the main natural cause of landslides (Buea and Limbe) and floods (Kumba and Limbe), and was generally also considered as a warning signal for floods. In Kumba it was noted that people will start to evacuate spontaneously once the water levels are rising above a critical point. Topography was also highlighted as a main cause of concern during the heavy rainy days. Nevertheless the causes of floods posing a risk to the population were largely ascribed to human activity: the waterways are narrowed and blocked as a result of "uncontrolled urbanisation" (Limbe and Kumba) with construction near river embankments. In marshy areas, the dumping of refuse in the rivers clogs up waterways. Deforestation is associated with a rise in erosion and landslide occurrence. An increased incidence of diseases as a result of waste transport in floods was highlighted as an associated population health risk in Kumba.

Damage to properties and loss of lives were mentioned as an impact of recent events. Construction in mapped disaster zones (Kumba) and on top of hills on old volcanic terrain (Limbe and Buea) was considered risky.

In Limbe, people have observed that three days of consecutive rainfall will cause people to worry about potential landslides. This timeframe fits well with that observed by Che et al. (2012b,) in their study of landslide occurrence and susceptibility in the Limbe area. In Kumba the population was aware that cracks opening up in the soil on a hill may also be a warning sign of an imminent landslide. Interestingly, the Kumba council acknowledged that removing landslide debris, e.g. clearing the roads, can in itself also pose a risk.

In Kumba, the Barombi crater lake flows into the frequently flooding Mabungise river. More importantly this river provides water and fish supplies to the city. Volcanic hazards were not mentioned in Kumba, which is understandable given the distance with respect to the volcano. In a previous workshop related to our VLIR-UOS project, the traditional chief of Kumba mentioned his concerns about the fish mortality and the risk of potential landslides of the crater walls and gas release from the lake. Previous occasions of fish mortality were related to the overturned stratified water after large rainfall leading to oxygen scarcity. Also as part of the same project, in 2010 information billboards on crater lake hazards were put up along the road towards the lake and at two entrances of the city (Fig. 2d). Nevertheless, gas release from the crater lake, i.e. similar to what happened at Lakes Nyos and Monoun in the 1980s, was not mentioned as a potential hazard by the FGD participants.

Tsunami was another type of hazard, mentioned in Limbe, a coastal town surrounded by hills with parts of the town lying below sea level. Coastal subsidence and erosion are active processes in Limbe, with a significant risk potential: sudden subsidence was observed in the late 1940s (cause unknown) as well as during past eruptive events of Mount Cameroon. In addition, gradual coastal erosion was observed through the rapid degradation of the coastal embankment that was built by the council.

The Buea and Limbe City Councils have well-established links with scientists at the University of Buea and/or the Geological Research Centre (also called Regional Research Centre) in Ekona from which they can obtain scientific information. The Buea councillors however admitted that the general level of hazard knowledge and awareness in the council was too low and dedicated information sessions would be most welcome. The Kumba Council is not 
connected to the Buea scientists but strongly welcomed researchers to approach the Council with information regarding hazards and risk. During the FGDs every council requested that the scientists actively provide information and possibly a training session about natural hazards and associated risk.

There is also collaboration with several Ministries in preparation for hazards, e.g. in the form of issuing building regulations and areas declared as high-risk zones for which building permits are in theory not issued. Nevertheless the councils all have limited financial resources, and limited to no facilities exist to manage hazardous events apart from providing basic first aid (Limbe).

A major and well-known problem enhancing the risk of floods and landslides is the disrespect of the building regulations and uncontrolled land use, with people still building houses in areas where they are not allowed to. In some cases those buildings are actively marked for demolition. However the implementation of the regulations, with actual evacuation of people from these zones and demolition of the buildings, does not typically seem to occur, except occasionally in Kumba. The local people are expected to go to the town planning service of the city council themselves to discuss their building plans and the regulations.

The town planning service, in charge of implementing building regulations, works with the related services at the national government level. The Mayor of Limbe indicated that the council is going through a process of increasing manpower to manage most of the regulations themselves, in light of new decentralisation policies. At the time of a disaster however, a special crisis commission is set up to manage it. No actual warning system exists and pre-event awareness-raising is limited to the existing billboards (specifically mentioned in Buea) and school education activities that were developed as part of our project. Commenting on the municipality regulations geared towards reducing risks, the participants agreed that, even if a scheme existed, decisions would still be largely taken "spontaneously" (Limbe).
In Kumba, an interactive communication system with a high penetration rate is in place, and is used to inform the population of the council's actions, but also to raise hazard awareness and issue active warnings in case of an event: "We use the local radio stations, churches, tribal groups, letters and sub-chiefs (in charge of particular neighbourhoods) to inform the population. There are 3 radio stations present in Kumba city. We have already established partnerships with these radio stations and we pay them on a monthly basis to disseminate information." There are specific radio programmes with interviews of departmental heads of the council. During these programmes the population is encouraged to participate and make direct enquiries using their mobile phones. In case of an emergency the people know they have to listen to the radio for updates. The council measures the degree of awareness from the reaction of the people. If they find the message does not get across, authorities change their strategy. Limbe and Buea had not yet developed such a communication system when the FGDs took place.

With respect to the engineering means available in Buea, the following comments were made:

It depends on the risk: for instance we have some means to manage something like the flood, we have the bulldozer if there is a flood; if there is a blockage we can rush and open up the gutters and so on but if it comes to natural disaster (e.g. the volcano) we do not have materials.

We know that we have to clean all the gutters of the community. If we neglect it, stones will block it and this will cause floods."

What is lacking is the knowledge that you people are giving us now. For instance, with the best of my knowledge we are 41 councillors but I don' $t$ know if up to 20 are aware that we may have a disaster at any time".

According to the participants from the three towns, little to no means are specifically reserved for hazard preparedness, mostly due to more pressing basic needs within the community. The 
councils will however take their responsibility in responding to an event and dealing with recovery as needed, and as is practically possible with the available resources.

\subsection{Crisis Response Structure and Communication}

Section B of the FGDs related to crisis management (Appendix, Table 1). In each town the participants explained the organisation of their respective council, although in Cameroon, the disaster risk management structure is centralised (Bang 2013, 2014).

In Buea, the councillors mentioned that, in case of an event, they "work closely with the Mayor, the Delegate Officer, the Governor and every other Ministry that will be in charge of the disaster, such as the Ministry of Scientific Research".

On how the council communicates risk to higher authorities, in Buea, the councillors said that "the committee in charge will go down to the field with the council workers in order to see what happened. They will alert the Mayor. He will be the one to call for any intervention from any Ministry... We have to report and then the Mayor takes it to higher quarters." "The mayor may now make a communiqué to the radio and then transmit it to the other services that are concerned". The power therefore seems to be relatively centralised in the hands of the Mayor in Buea.

When a significant event occurs, the Ministry of Scientific Research and Innovation and the University of Buea will provide information and work in close collaboration with the council and their monitoring units. When questioned about the existence of an early warning system however, the councillors did not really understand what this would encompass.

Kumba is not a city council sensu stricto but a municipality with a Government Delegate in charge of the urban councils. After receiving written technical reports from the various departments in case of an event, the Government Delegate decides and authorises the actions to solve the problems, since he holds the financial resources. In reality no written document is sent to the Government Delegate, as technically required, but communication occurs directly by telephone, especially in case of an emergency. During an emergency, basic equipment and facilities are made available to deal with immediate response on the ground. This includes equipment for dredging rivers where needed, e.g. in case of floods, but also assistance to the community with burying victims.

In Limbe the engineer reported that many disasters take the community by surprise, but that the council would organise an evacuation dependent on sufficient resources. This is the only time that evacuation is mentioned. Later in the discussion, the Mayor further described the communication to be easy these days: "When a natural disaster occurs it goes around like wild fire". He referred to the fact that many people use mobile telephones for communicating via text messages (SMS). They may also make use of social media and informal communication channels within the neighbourhoods. The local authorities would also call the scientists. For instance, at the time of the 2010 landslide the Mayor immediately called the $\mathrm{PhD}$ researcher (author VBC) he had met at a previous workshop. He had at the time also requested immediate clearing of the road (main evacuation for the town along the ocean).

In every town, FGD participants requested education by the scientists on disaster preparedness. A better understanding of the causes of the hazards, e.g. supported by landslide susceptibility maps, would help in the evacuation of certain areas at critical moments before a disaster ensues, but also in implementing building regulations in the first place. Participants also wanted to know more about precursory signs of imminent events and the potential deployment of monitoring equipment.

\subsection{Recovery and Reconstruction}

None of the cities has a dedicated post-event recovery program of actions (Table 1 ). In Buea the participants mentioned that a special council session would be held to discuss housing and 
financial assistance needs after properties have been destroyed by an event. The councillors would then report to the Governor and the Minister in charge (e.g. Public Health, in case of a risk of cholera outbreak). The level of support provided by the regional and national authorities will depend on the scale of the disaster.

In Limbe, the participants complained about promises made by some private companies to rebuild houses after the last landslide crisis. These promises were not met, and the buildings were finally occupied by a school.

The Limbe council itself is performing sensitisation actions: the people should not farm or build houses in a landslide-prone area (e.g. also billboard shown in Fig. 2c). Instead, tree planting is encouraged. At the council level, they aim to implement stringent building rules and regulations. However they conceded to have a lack of strategic planning at the council level, and instead referred to the Department of Civil Protection at the Ministry of Territorial Administration and Decentralisation in Yaoundé.

In Kumba, funds for response and recovery are limited but directly available, e.g. for dredging rivers. The funds are provided by the Government Delegate and are part of the annually reviewed budget for risk management, and so rivers are regularly cleaned and dredged both before and after events. At the end of each FGD, participants agreed that a decentralisation of the risk management process, under the authority of the Ministry of Territorial Administration and Decentralisation, would be highly advisable, especially for the councils of Buea and Limbe. Discussions between the Ministries and Government Delegates and the local Mayors related to disaster response and recovery were reported to be limited.

\section{Discussion}

The FGDs revealed that the main hazards and risks, e.g. landslides, floods, seismic and volcanic hazards are generally well perceived. Precursory signals of floods and landslides are recognised as well as tremors as signs for volcanic activity. Because of their higher recurrence rates, landslides and floods are clearly the most pressing concerns to the local communities in terms of natural hazards. Volcanic hazards are of less concern, due to either the relatively frequent but small-scale eruptions typical for Mount Cameroon with limited impact on the urban infrastructure, or the infrequent nature of events such as crater lake outgassing, which do not occur in the living memory of most of the local population. This is reflected in the more limited awareness of these events relative to landslides and floods. We expect that the communication and response practices developed for frequent landslide/flood emergencies - with a background of limited financial resources - will be adopted at similar levels in case of a volcanic crisis. Most FGD participants however agreed that they need more technical information about the nature and causes of hazards that may affect their communities in the future, as well as about appropriate preventive measures.

The scientists realised from their side that they did not make enough pro-active effort on a regular basis to communicate the outcomes of their research. For example, the billboards installed in the framework of the VLIR-UOS project turned out to have limited impact to increase awareness. They were installed with consent of the councils, but councillors were not further informed about the message and purpose of these billboards. Such activities were instead limited to teachers and radio show hosts. Incorporating indigenous knowledge, e.g. passed on by traditional chiefs, into technical assessments and a range of awareness-raising actions may further help local inhabitants to better understand and appreciate natural events, and also behave adequately in case of an emergency.

Facilities to manage risk are practically non-existent except for assistance by the Civil Protection at the national level, intervening only in the case of large-scale events. This lack of adequate means and infrastructure in each of the cities remains a concern. Regional risk management is not yet effectively in charge of taking 
decisions to prevent disasters, to handle crises and to recover from or mitigate future events. Continuous occupation of risk zones by new buildings, and the absence of temporary evacuation or relocation plans at the city level are other bottlenecks in the effective reduction of risk impacts.

The general lack of prevention and preparedness actions of local councils is understandable in a country where risk management decisions are mostly taken by Ministries. The fact that the regulations regarding risk management are centralised makes it more complicated to apply actions and adapt communication strategies to the local context. It is clear that the communication chain to the population, e.g. with the use of frequent radio programmes, is best developed in Kumba, which is directly governed by a Government Delegate. The other local authorities are however poorly informed about any preparedness or prevention strategies that may exist at the national level. In addition to centralised regulations, illegal construction and lack of regulation enforcement on the ground are major bottlenecks for the efficiency of any prevention schemes.

The response scheme to hazardous events is largely characterised by spontaneous actions within the community and informal communication channels. Strong social networks typical for African communities strengthen the effectiveness of this informal communication. Although risk management commissions are officially defined, the communication and the decision process during events rely mostly on ad hoc communication between the affected population, local authorities and scientists. The Mayor and the City Council are the main actors for responding to impact, however with limited means. The leadership of the local Mayor and councillors, and their relationship to the national government, via the Government Delegate, control whether more resources and recovery support can be provided. As Kumba depends directly on the Government Delegate, more preventive and response actions are immediately undertaken thanks to rapid money allocation. In Buea and Limbe however, actions are delayed due to intermediate administrative levels between the Government Delegate and the City Council.

Effective collaboration between local and national authorities, as well as trust and frequent communication between local decision-makers, scientists and the population and their representatives are essential elements in the effectiveness of the management of hazardous events (Barclay et al. 2008). The awareness by the Mayors and councillors for the need of risk reduction actions, as well as the available means are other key elements. The personal participation of the Mayor of Limbe in the FGD demonstrated his interest and dedication. The FGD led to a fruitful exchange between the Mayor and several of the local chiefs, all of them feeling highly responsible for risk management in their local communities. The actions taken within the VLIR-UOS project, including the FGDs, have thus contributed to enhancing the relationships between the city councillors, mayors and scientists.

\section{Conclusions}

FGDs have the advantage of enabling interactions between all actors, with the opinion of all participants being considered at an equal level. Our FGDs contributed to increasing the awareness of risks among the councillors and to identifying the current state and limitations of the schemes aimed at preparing for, responding to and mitigating impacts of natural hazards in the vicinity of Mount Cameroon. The outcome of the FGDs is useful for the scientists and also contributes to raising participants' awareness about the need to address the different steps of the risk management cycle and the challenges faced in implementing them effectively (i.e. scientific knowledge, education and communication actions, preparedness and response plans, resource allocation and decision-making structure).

The scientists who are part of this project have realised they perhaps do not always make enough effort to actively communicate their relevant research results to the local communities and stakeholders. The relationship between the local authorities and the local scientists will hopefully 
continue to develop in the future, as requested by all FGD participants. Transfer of knowledge and leadership of the local authority are essential for implementing mitigation and preparedness actions and for effective coordination of the actions during and directly following a crisis.

Decentralisation of the decision process was the main wish expressed from all the councils that took part in our FGDs. Decentralisation of the governmental coordination of risk management related to local natural hazards would allow the development of a locally relevant plan of action to turn disaster prevention policies into practice. However decentralisation of the decision will lead to potential improvement only when associated with availability of sufficient funding earmarked to support implementation.

Acknowledgements This project was supported by the Flemish Interuniversity Council-University Development Cooperation (VLIR-UOS), granted to Ghent University and the University of Buea. Karen Fontijn is currently supported by the UK's Natural Environment Research Council grant NE/L013932/1 ("RiftVolc"). We are extremely grateful to all participants of the focus group discussions, as well as numerous people at the University of Buea, research institutes and city councils who have facilitated this work. Constructive reviews by Carina Fearnley and an anonymous reviewer have helped improve this manuscript.

\section{Appendix: Focus Group Discussion Questions Guiding the Discussions Hosted by a Local Moderator}

\section{Code A - Preparedness}

1. Do you perceive any natural hazard in your municipality that could constitute risk?

- If yes, what are the hazards?

- What are the causes?

- How do these hazards constitute risk?

- What are the warning signs of these events?

- From where and whom do you expect to get reliable information on the possible risks associated to the hazard?
2. Is there any scheme in preparation for disaster?

- Does your municipality have regulations geared towards reducing risk?

- Is there anyone in the municipality in charge of implementing such a scheme?

- Does the municipality possess facilities to manage risk?

3. Are there any warning systems in place to alert the population (incase of an emergency) of the risks associated with a natural hazard?

- If yes, elaborate

- Is the population properly informed about it?

- Besides these, are you aware of any other tools that can be used to enhance the warning efficacy?

\section{Code B - Response}

1. How do you communicate risk to the population?

- How do you anticipate the population's response to your warnings?

- What language would you use to reach out to the threatened population?

- How do you evaluate the success of your communication?

2. How do you communicate risk with higher authorities?

3. How do you liaise with researchers/scientists? About...

- Effects to the physical environment

- Psychological impacts

- Economic distortions

4. What will be your immediate response when there is a crisis?

5. What is the last crisis that the municipality experienced?

6. What where the impacts of this crisis?

- Effects to the physical environment

- Psychological impacts

- Physical health

- Economic impacts

- Social impacts. 


\section{Code C-Recovery}

1. Does the council have a strategy for helping people to overcome the basic problems within a year of the crisis?

2. Was this strategy used during the last crisis?

\section{Code D - Mitigation ( Reconstruction )}

1. Drawing from past experience and knowledge, are there any policy measures to guarantee long lasting solutions to managing risk resulting from natural hazards in your municipality?

- Source of policy?

2. Are there strategies to back up this policy? (probe for strategies and documentation)

3. How are you implementing the strategies? (probe for ongoing action)

4. What other strategies and actions are envisaged by your municipality?

\section{References}

Atanga MBS, Van der Meerve A, Shemang EM, Suh CE, Kruger W, Njome MS, Asobo NE (2009) Volcanic ash from the 1999 eruption of Mount Cameroon volcano: characterization and implications to health hazards. J Cameroon Acad Sci 8:63-70

Atanga MBS, Van der Meerwe AS, Suh CE (2010) Health system preparedness for hazards associated with Mount Cameroon Eruptions: a community perspective from Bakingili Village, Cameroon. Int J Mass Emerg Disasters 28:298-325

Ateba B, Dorbath C, Dorbath L, Ntepe N, Frogneux M, Aka FT, Hell JV, Delmond JC, Manguelle D (2009) Eruptive and earthquake activities related to the 2000 eruption of Mount Cameroon volcano (West Africa). J Volcanol Geotherm Res 179:206-216. doi:10.1016/ j.jvolgeores.2008.11.021

Ayonghe SN, Ntasin EB, Samalang P, Suh CE (2004) The June 27, 2001 landslide on volcanic cones in Limbe, Mount Cameroon, West Africa. J Afr Earth Sci 39:435-439. doi:10.1016/j.jafrearsci.2004.07.022

Bang HN (2013) Governance of disaster risk reduction in Cameroon: the need to empower local government. Jàmbá: J Disaster Risk Stud 5: Art. \#77, 10pp. doi: 10.4102/jamba.v5i2.77X

Bang HN (2014) General overview of the disaster management framework in Cameroon. Disasters 38:562-586
Barclay J, Haynes K, Mitchell T, Solana C, Teeuw R, Darnell A, Crosweller HS, Cole P, Pyle D, Lowe C, Fearnley C, Kelman I (2008) Framing volcanic risk communication within disaster risk reduction: finding ways for the social and physical sciences to work together. Geol Soc London Spec Publ 305:163-177. doi:10.1144/SP305.14

Bohnsack R (2004) Group discussions and focus groups. In: Flick U, von Kardorff E, Steinke I (eds) A companion to qualitative research. Sage Publications, USA, pp 214-221

Bonne K, Kervyn M, Cascone L, Njome S, Van Ranst E, Suh E, Ayonghe S, Jacobs P, Ernst GGJ (2008) A new approach to assess long-term lava flow hazard and risk using GIS and low cost remote sensing: the case of Mount Cameroon, West Africa. Int J Remote Sens 29:6539-6564. doi:10.1080/01431160802167873

Che VB, Kervyn M, Ernst GGJ, Trefois P, Ayonghe S, Jacobs P, Van Ranst E, Suh CE (2011) Systematic documentation of landslide events in Limbe area (Cameroon): their geometry, sliding mechanism, controlling and triggering factors. Nat Hazards 59:47-74. doi:10.1007/s11069-11011-19738-11063

Che VB, Fontijn K, Ernst GGJ, Kervyn M, Elburg M, Van Ranst E, Suh CE (2012a) Evaluation of the degree of weathering in landslide-prone soils in the humid tropics: the case of Limbe (SW Cameroon). Geoderma 170:378-389. doi:10.1016/j.geoderma. 2011.10.013

Che VB, Kervyn M, Suh CE, Fontijn K, Ernst GGJ, del Marmol M-A, Trefois P, Jacobs P (2012b) Landslide susceptibility assessment in Limbe region ( $\mathrm{SW}$ Cameroon): a field calibrated seed cell and information value method. Catena 92:83-98. doi:10.1016/j. catena.2011.11.014

Che VB, Trefois P, Kervyn de Meerendre M, Ernst GC, Van Ranst E, Verbrugge J-C, Schroeder C, Jacobs P, Suh CE (2013) Geotechnical and mineralogical characterisation of soils from landslide scars and inferred sliding mechanism: case of Limbe, SW Cameroon. Glob Environ Change landslide Sci Pract 4: 43-49. http://link.springer.com/chapter/10.1007\%2F978-3_ 642-31337-0_5

Déruelle B, N'ni J, Kambou R (1987) Mount Cameroon: an active volcano of the Cameroon Line. J Afr Earth Sci 6:197-214. doi:10.1016/0899-5362(87)90061-3

Déruelle B, Ngounouno I, Demaiffe D (2007) The 'Cameroon Hot Line' (CHL): a unique example of active alkaline intraplate structure in both oceanic and continental lithospheres. C R Geosci 339:589-600. doi:10.1016/j.crte.2007.07.007

Diko ML (2012) Community engagement in landslide risk assessment in Limbe, Southwest Cameroon. Sci Res Essays 7(32):2906-2912. doi 10.5897/SRE12.488 http://www.academicjournals.org/SRE

Donovan A, Eiser JR, Sparks RSJ (2014) Scientists' views about lay perceptions of volcanic hazard and risk. J Appl Volcanol 3:15. doi:10.1186/s13617-0140015-5 
Favalli M, Tarquini S, Papale P, Fornaciai A, Boschi E (2011) Lava flow hazard and risk at Mt. Cameroon volcano. Bull Volcanol 74:423-439. doi:10.1007/ s00445-011-0540-6

Fothergill A (1996) Gender, risk, and disaster. Int J Mass Emerg Disasters 14(1):33-56

Freeth SJ, Kay RLF (1987) The lake Nyos gas disaster. Nature 325:104-105. doi:10.1038/325104a0

Gaillard J-C, Dibben CJL (2008) Volcanic risk perception and beyond. J Volcanol Geotherm Res 172:163-169

GEADIRR (2011) Geotechnology, environmental assessment and disaster risk reduction. Views from the Frontline (VFL) Cameroon report to the Global Network for Civil Society Organizations for Disaster Reduction (GNDR)

Gehl P, Quinet C, Le Cozannet GG, Kouokam E, Thierry P (2013) Potential and limitations of risk scenario tools in volcanic areas through an example at Mount Cameroon. Nat Hazards Earth Syst Sci 13:2409-2424. doi:10.5194/NHESS-13-2409-2013

Issa OT, Chako Tchamabé B, Padrón E, Hernández P, Eneke Takem EG, Barrancos J, Sighomnoun D, Ooki S, Nkamdjou Sigha, Kusakabe M, Yoshida Y, Dionis S (2014) Gas emission from diffuse degassing structures (DDS) of the Cameroon volcanic line (CVL): implications for the prevention of $\mathrm{CO}_{2}$-related hazards. J Volcanol Geotherm Res 283:82-93. doi:10. 1016/j.jvolgeores.2014.07.001

Mercer J, Kelman I (2010) Living alongside a volcano in Baliau, Papua New Guinea. Disaster Prev Manag 19:412-422

Ndille R, Belle JA (2014) Managing the Limbe floods, considerations for disaster risk reduction in Cameroon. Int J Disaster Risk Sci 5:147-156. doi:10.1007/ s13753-014-0019-0

Njome MS, de Wit MJ (2014) The Cameroon line: analysis of an intraplate magmatic province transecting both oceanic and continental lithospheres: constraints, controversies and models. Earth Sci Rev 139:168-194. doi:10.1016/j.earscirev.2014.09.003

Njome MS, Suh CE, Sparks RSJ, Ayonghe SN, Fitton JG (2008) The Mount Cameroon 1959 compound lava flow field: morphology, petrography and geochemistry. Swiss J Geosci 101:85-98

Njome MS, Suh CE, Chuyong G, de Wit MJ (2010) Volcanic risk perception in rural communities along the slopes of Mount Cameroon, West-Central Africa. J Afr Earth Sci 58:608-622. doi:10.1016/j.jafrearsci. 2010.08.007
Pannaccione Apa MI, Kouokam E, Akoko RM, Nana C, Buongiorno MF (2012) An ethical approach to socio-economic information sources in ongoing vulnerability and resilience studies: the Mount Cameroon case. Annal Geophys 55:3. doi:10.4401/ag-5569

Siebert L, Simkin T, Kimberly P (2010) Volcanoes of the world, 3rd edn. University of California Press, Berkeley

Suh CE, Sparks RSJ, Fitton JG, Ayonghe SN, Annen C, Nana R, Luckman A (2003) The 1999 and 2000 eruptions of Mount Cameroon: eruption behaviour and petrochemistry of lava. Bull Volcanol 65:267-281. doi:10.1007/s00445-002-0257-7

Suh CE, Luhr JF, Njome MS (2008) Olivine-hosted glass inclusions from scoriae erupted in 1954-2000 at Mount Cameroon volcano, West Africa. J Volcanol Geotherm Res 169:1-33. doi:10.1016/j.jvolgeores. 2007.07.004

Suh CE, Stansfield SA, Sparks RSJ, Njome MS, Wantim MN, Ernst GGJ (2011) Morphology and structure of the 1999 lava flows at Mount Cameroon Volcano (West Africa) and their bearing on the emplacement dynamics of volume-limited flows. Geol Mag 148:2234. doi:10.1017/S0016756810000312

Thierry P, Stieltjes L, Kouokam E, Ngueya P, Salley PM (2008) Multi-hazard risk mapping and assessment on an active volcano: the GRINP project at Mount Cameroon. Nat Hazards 45:429-456. doi:10.1007/ s11069-007-9177-3

Wantim M, Suh CE, Ernst GC, Kervyn M, Jacobs P (2011) Characteristics of the 2000 fissure eruption and lava flow fields at Mount Cameroon volcano, West Africa: a combined field mapping and remote sensing approach. Geol J 46:344-363. doi:10.1002/gj.127

Wantim M, Kervyn M, Ernst GC, del Marmol M-A, Suh CE, Jacobs P (2013a) Morpho-structure of the 1982 lava flow field at Mount Cameroon volcano, West-Central Africa. Int J Geosci 4:564-583. doi:10. 4236/ijg.2013.43052: http://www.scirrp.org/journal/ ijg

Wantim MN, Kervyn M, Ernst GGJ, del Marmol M, Suh CE, Jacobs P (2013b) Numerical experiments on the dynamics of channelized lava flows at Mount Cameroon volcano with the FLOWGO thermo-rheological model. J Volcanol Geotherm Res 253:35-53. doi:10.1016/j.jvolgeores.2012.12.003

Wilkinson S (2004) Focus group research. Qualitative research: theory, method and practice. Sage Publications, London 
Open Access This chapter is licensed under the terms of the Creative Commons Attribution 4.0 International License (http://creativecommons.org/licenses/by/4.0/), which permits use, sharing, adaptation, distribution and reproduction in any medium or format, as long as you give appropriate credit to the original author(s) and the source, provide a link to the Creative Commons license and indicate if changes were made.
The images or other third party material in this chapter are included in the chapter's Creative Commons license, unless indicated otherwise in a credit line to the material. If material is not included in the chapter's Creative Commons license and your intended use is not permitted by statutory regulation or exceeds the permitted use, you will need to obtain permission directly from the copyright holder. 